\title{
Sciendo
}

HOLISTICA Vol 10, Issue 3, 2019, pp. 143-156

\section{Imitation vs Innovation: Is there an alignment between supply chain organizational learning and Islamic HRM practices?}

MUAFI,

Department of Management, Economic Faculty, Universitas Islam Indonesia

Email: muafi@uii.ac.id (Corresponding author)

QUROTUL UYUN,

Department of Clinical Psychology, Universitas Islam Indonesia

\begin{abstract}
This research emphasizes on the importance of having an alignment of organizational strategy (innovation and imitation) with supply chain organizational learning, and Islamic HRM practices toward Batik MSMEs performance in Pekalongan, especially environmental, social, and religious performance. The population of this research is Batik MSMEs in Pekalongan, Central Java, Indonesia. Pekalongan is known as the City of Batik and has religious society that can live in peace although they live side by side with different religion and ethnicity. The respondent of this research is Batik MSMEs owner/manager in Pekalongan City that is counted using purposive sampling technique about 170 respondents. The statistic technique is using Euclidience Distance Regression. After organizational strategy being tested separately, it is proved that there is an alignment between organizational strategy both innovation and imitation with innovation organizational learning and imitation organizational learning. There is also an alignment of organizational strategy both innovation and imitation in innovation Islamic HRM Practices and conservative Islamic HRM Practices. The theoretical implication in this research provides a theory contribution about the importance of alignment of organizational strategy with the contingency of supply chain organizational learning and Islamic HRM practices. The managerial implication is that while improving organizational performance, organization needs to have practical policy in the alignment of organizational strategy with the contingency of supply chain organizational learning and Islamic HRM practices.
\end{abstract}

Keywords: Supply Chain organizational Learning, Islamic HRM practices, Organizational Strategy, Organizational Performance

JEL Classification: M5.

\section{Introduction}

Business continuity of an organization is determined by the ability of the organization in maintaining its business. Market competition requires company to 
have superiority compared to its competitors. The increasingly rapid market development must be balanced with the knowledge that exists in the company. In this case, the company must continue to increase production to meet consumer demand, maintain quality, and innovate with their product through knowledge and learning (Stelmaszczyk, 2016). Therefore, the improvement of company's capabilities needs to be carried out continuously in the company. One of the conditions to obtain good output or result is the right attention from the management to the individuals under it. Company leaders have an important role in encouraging and directing their members below to continue to learn and be able to implement good human resources management practices in order to achieve organizational performance(Walton \& Lawrence; 1985; Schuler \& Jackson, 1987; Delaney, \& Husehild, 1996; Alleyne, et al., 2005; Bernadin \& Russel, 1998). This research emphasizes in environmental, social, and religious performance of Batik MSMEs in Pekalongan City, Central Java Province, Indonesia. It is because there are several prior researches that have been conducted business performance aspects of Batik MSMEs in Indonesia, especially in Pekalongan.

The other reason is because Pekalongan City is known as city of santri (Islamic school student) with the majority of population being Moslem. They can live side by side in peace and harmony with people with different ethnic, such as Chinese and Arabs. This is very interesting considering that batik entrepreneurs in Pekalongan City have a very high religiosity aspect and the entrepreneurs are known to have a high social soul in the surrounding community. But on the negative side, they have hedonic behavior and a very high prestige to maintain their social status as entrepreneurs. Batik industry in Pekalongan continues to grow and develop rapidly in the midst of high level of industry competition both in local and between regions. This very complex and competitive competition requires entrepreneurs to compete from the prices, product quality, and the services offered. Therefore, Batik MSMEs in Pekalongan need to have a level of organizational strategy alignment with the contingency that is faced, such as in organizational learning and Islamic HRM practices in order to increase organizational performance (environmental, social, and religious). 


\section{Literature Rieview}

\section{Organizational Strategy and Islamic HRM Practices}

Miles and Snow (1978) explained that organizational strategy is a translation of the external and internal environmental analysis to identify threats, opportunities, strengths, and weaknesses of the company. It is done so that the company can have alternative strategies that are available so that they can implement it right on target. When the company can operate efficiently and effectively, it means that the company can establish a mechanism that can support its organizational strategy, and vice versa. The organizational strategy of a company will be related to the organizational structure and processes. In the study from Schuler and Jackson (1987) it is explained that there is a relation between innovation strategy, quality enhancement, and cost reduction with HRM practices. HRM practices play an important role in meeting employee expectations in order to increase their sale value in a long term (Bou \& Beltran, 2005). The selection of HRM practices must be done carefully, not to be careless. This is because the selection of HRM practice will have a strong influence on behavior. If it is used wisely, systematically, and according to consumer needs, employees, and company business strategy, then this kind of practice will change the lowperformance companies into high-performance companies. If it is used unwisely, then chaos will occur. HRM practices can be used to obtain and maintain a competitive advantage. When determining HRM practices related to competitive strategies, organization can choose several dimensions of HRM practices introduced by Schuler dan Jackson (1987).

Huselid, et al. (1997) stated that HRM practices are divided into two: technical HRM and strategic HRM. This division is based on regulatory and administrative functions. Technical HRM practices emphasize on regulatory and administrative processes, while strategic HRM practices emphasize empowerment and social interaction function. Some researches that examines the influence of HRM practice and organizational strategy toward organizational performance has also been carried out by researchers. It is emphasized that innovative HRM practices will be in line with innovative strategies, and vice versa. An conservative HRM practices will also be in line with efficiency strategies (Husehild, et al., 1997; Husehild, 1995). Jimenez-Jimenez \& Sanz-Valle (2005; Schuler and Jackson, 1987) 
provide recommendations that there is a need for organizations to have an alignment between organizational strategy and HRM practices. It is important so that organizational performance continues to increase.

Islamic HRM practices is always related to the application of Islamic principles in the aspect of human life at work. Islam requires the leader to treat employees to work comfortably and safely. In the aspect of life, Islam considers work as a part of worship and perfects work as an obligation of religion. Islam builds employee welfare and balances work and life (Ali, 2010; Ab. Rahman et al., 2013; Ahmad, 2015). Moideenkutty et al. (2011) stated that organization that can harmonize their human resources practice with Islamic principles will tend to perform better (Moideenkutty et al., 2011; Ab. Rahman et al., 2013;; Ahmad, 2015). The research result fromFarouk et al. (2016) proved that the interaction effect of innovation strategy in HRM practices (selection) have a significant and positive impact on improving organizational performance. This result is supported by Rana and Malik (2017; 2016) thatHR Practices (selection, training, compensation, performance appraisal, and employee participation)generated a significant and positive relationship toward organizational performance moderated by Islamic principles. This result is strengthened by Azmi (2010; 2015; Ahmad, 2015; Rahman et al., 2013) that it is important to strengthen Islamic principles in HRM practices to improve organizational performance.

\section{Organizational Strategy and Supply Chain Organizational Learning}

Leaders must be able to make their organization a learning organization that continues to learn and develop continuously in order to have superior organizational performance above the average. In addition, companies that are increasingly developing will experience many problems that can make individuals in it learn. Evaluations that carried out by leaders and members in the company can be used as learning material so that they can develop quality and innovate on products to have an advantage in the eyes of stakeholders. Organizational learning is strongly related to individuals, group, or the organizations itself. Companies can have high superior value if the company has resources, especially human resources that have knowledge to improve company performance. The success of organizational learning is not only determined by individuals in the organization, 
but the efficiency of groups or teams within the organization also has to be considered (Stelmaszczyk, 2016).

The terms organizational learning and learning organizationare often used interchangeably. Basically, both have different meaning. Learning organizations are the organizations that help the learning from individual and continuously change themselves (Farrukh \& Waheed, 2015; Jyoti et al., 2017). The definition of learning organization according to Pendler et al. (1988, in Rowley, 2006)is the organization that facilitates learning from all its members and continually changes itself. Organizational learning as explained earlier is centered on leaders who encourage members to carry out continuous learning. Leaders can also do learning by following training, seminars, and other activities that are able to increase their knowledge and then transmitted to members within the company. The responsibility for organizational learning also lies with the leader (Imran et al., 2016). Gorelick (2005) stated that organizational learning and learning organization are two interrelated things. Organizational learning can grow and develop if it is supported by a good learning organization. A good organizational learning cycle in the company can encourage individuals in the company to increase their knowledge and dig deeper information to help them manage the company well. This is supported by the statement from Senge et al. (1994, inGorelick, 2005)namely:organizational learning and learning organization can and must coexist. In addition, Gorelick (2005)stated that basically, to be an effective learning organization, there is a need for deep learning cycle and recognition that it will take time.

It is known that MSMEs in Indonesia are experiencing obstacles in learning methods, tools, and management related to its supply chain. However, business always run dynamically and the supply chain cannot be static. In carrying out raw material purchase, production process, until marketing process, MSMEs are faced with lack of knowledge and technology (Hamidin \& Surendro, 2010). The research result from Ikhwan (2017) explained that the sub system of learning organization that have the greatest value is human resources, knowledge, organization, and technology. Organization with members who have strong willingness to learn about supply chain can have a positive effect on the supply chain driver that will also have an impact on supply chain performance. Supply chain performance can be increased by implementing organizational learning through: optimizing and 
maintaining owned resources, utilizing market information well, and following up market information by selling their product competitively. Therefore, with a good organizational learning, it is expected that organization can implement the application of production activity network until distribution which includes human resources that can meet dynamic consumer demands nowadays. By having an excellent knowledge, it will avoid imitation from the competitors because each MSME will have its own uniqueness and superiority of each product that is produced (Lei, et al., 1996) and can operate efficiently (Hitt, et al., 2001).

According to Bolton (1983) there are two typological approaches to make organization has a competitive advantage for new knowledge development, which is innovation and imitation. The inherent characteristics of each innovation strategy (innovation vs. imitation) are: (1) the main process through learning by doing vs. transferring; (2) the source of knowledge through internal vs. external; (3)the main asset types are specialized vs. generic; (4) the required R\&D investments areheavy vs. low, (5) information flow through internal vs. one way, (6) the types of knowledge are entirely now vs. new to company. If there is an alignment between organizational strategy and organizational learning, the organization will be able to improve organizational performance and competitive advantage of the company in the long run (Hurley \& Hult, 1998). The research result from A.S. and Arief (2017) stated that MSMEs organization nowadays are encouraged to have organic organization design in order to be able to drive the individual in the organization to have innovative behavior, increase efficiency, and carry out effective changes

H1. The more the alignment between organizational strategy (imitation) with the variable of Islamic HRM Practices (conservative), the more it can improve organizational performance (environmental, social, and religious) in a contingency, and vice versa.

H2. The more the alignment between organizational strategy (imitation) with the variable of organizational learning (imitation), the more it can improve organizational performance (environmental, social, and religious) in a contingency, and vice versa.

H3. The more the alignment between organizational strategy (innovation) with the variable of Islamic HRM Practices (innovation), the more it 
can improve organizational performance (environmental, social, and religious) in a contingency.

H4. The more the alignment between organizational strategy (innovative) with the variable of organizational learning (innovative), the more it can improve organizational performance (environmental, social, and religious) in a contingency.

\section{Research Method}

This research is conducted in Batik MSMEs in Pekalongan City, Central Java, Indonesia. Pekalongan is known in the world as a city of Batik and can prove to be a religious community that can live peacefully alongside different ethnicities. The respondents of this research are the owners/managers of Batik MSMEs in Pekalongan City that is collected using purposive sampling technique of 170 respondents. The research sample is mostly the MSMEs which spread in 18 urban villages. The purposive sampling technique is chosen on the condition that the MSMEs have been operated for at least 5 years and the owners/managers of the MSMEs are Moslem. The measurement of Islamic HRM (IHRM) and organizational learning (OL) variables is done using semantic differential scale start from scale 1 (very strongly not emphasized) to scale 7 (very strongly emphasized). Generic HRM practices in this study have been combined with Islamic Value so that Islamic terms have been added in each HRM practice to clarify measurement. Specifically, for organizational performance variable (environmental, social, and religious) is done by asking the owner/manager to compare their performance with the performance of competing companies, on scale 1 (very low) to scale 7 (very high). The statistic technique is using Regression Euclidience Distance. It is done by looking at the simple linear regression coefficient by contingency approach. Negative and significant coefficient number is sought because it means that the greater the ED score, the smaller the fit between variable (the distance between variables is closer) so that it will have a negative effect on performance. This indicates that it will be able to improve organizational performance, and vice versa. The validity and reliability test results of the researched variable items show that all items are valid and reliable. 


\section{Results}

This research uses organizational strategy data of 170 MSMEs that choose organizational strategy of imitation and innovation. Furthermore, the data will be divided into two groups of strategies with the cut off value of 3.5 (range of scores from 1 to 7); (1) imitation of 104 MSMEs, and (2) innovation of 66 MSMEs. The two groups are then tested using ANOVA model (analysis compare means one way ANOVA). The test result shows that there is a significant difference between imitation strategy (code 1 ) and innovation strategy (code 2) with sign $\mathrm{F}=0.00$.

The hypothesis test are then done using a simple linear regression model with the equation:

$\mathrm{Y}=\mathrm{a}+\mathrm{bDist}+\mathrm{e}$. The equation means:

$Y$ is organizational performance;

a is a constant;

$\mathrm{b}$ is the regression coefficient; and Dist is Euclidian Distance variable.

Simple regression analysis is used to test the hypothesis as stated in $\mathrm{H} 1$ to $\mathrm{H} 4$ and it is carried out to all data, namely the number of imitation and innovation groups. In the simple linear regression, each independent euclidian distance variable is tested for its effect on organizational performance. The results of the test are summarized on Table 1 dan Table 2. The t-test results show that the significance of each hypothesis is less than 0,05 , which means that $\mathrm{H} 1, \mathrm{H} 2, \mathrm{H} 3$ and $\mathrm{H} 4$ are accepted.

\section{Regression Analysis of Imitation Strategy Group}

The regression test result presented on Table 1 is the hypothesis test ( $\mathrm{H} 1$ and $\mathrm{H} 2$ ) in the imitation strategy group.

Table 1. Regression Test Result of Imitation Group ( $n=104)$

\begin{tabular}{|c|c|c|c|c|}
\hline Regression equation model & Constant & $\begin{array}{c}\text { Coeffisients } \\
\text { (beta) }\end{array}$ & t count & sign \\
\hline 1. $\mathrm{Y}=\mathrm{a}+\mathrm{b} 1$ dist (Strat.IHRM)+e & 6.380 & -0.284 & -2.995 & $0.003^{*}$ \\
\hline 2. Y $=\mathrm{a}+\mathrm{b} 1$ dist (Strat.OL)+e & 6.338 & -0.254 & -2.647 & $0.009^{*}$ \\
\hline $\begin{array}{c}\text { 3. } \mathrm{Y}=\mathrm{a}+\mathrm{b} 1 \text { dist } \\
\text { (Strat.IHRM.OL)+e }\end{array}$ & 6.288 & -0.217 & -2.103 & $0.003^{*}$ \\
\hline
\end{tabular}

Note:* sign. $<0.05$ 


\section{Regression Analysis of Innovation Strategy Group}

The regression test result presented on Table 2 is the hypothesis test (H3 and $\mathrm{H} 4$ ) in the innovation strategy group.

Table 2. Regression Test Result of Innovation Group ( $n=66$ )

\begin{tabular}{|c|c|c|c|c|}
\hline Regression equation model & Constant & $\begin{array}{c}\text { Coeffisients } \\
\text { (beta) }\end{array}$ & t count & sign \\
\hline $\begin{array}{c}\text { 1. } \mathrm{Y}=\mathrm{a}+\mathrm{b} 1 \text { dist } \\
\text { (Strat.IHRM)+e }\end{array}$ & 6.408 & $-0,375$ & -3.233 & $0.002^{*}$ \\
\hline 2. Y = a + b1 dist (Strat.OL)+e & 6.344 & -0.489 & -4.483 & $0.000^{*}$ \\
\hline $\begin{array}{c}\text { 3. Y = a + b1 dist } \\
\text { (Strat.IHRM.OL)+e }\end{array}$ & 4,618 & -0.403 & -3.175 & $0.002^{*}$ \\
\hline
\end{tabular}

Note:* sign. $<0.05$

It can be concluded that hypothesis 3 and hypothesis 4 are accepted.

6. Discussion, and Conclusions

Human resources in the company can either be the biggest assets or the biggest obligation for the company. Every organization has a different scope and method of managing HR. In general, policies related to the management of human resources in an organization can be decided by senior managers from the company which carried out with or without consultation with their employees. Employers and employee must have a commitment and trust to one another. The more someone is commited to his religion, the more he will commit to his work. Therefore, according to Islam, if someone is working more dedicated in accordance with his beliefs and the conditions agreed upon in the company, he will justify his income and likelihood that he accepted and he can be an example for people who have the same faith and beliefs. It would not just having a psychological and transactional contract relationship. To plan a resources on Islamic cultural lines, general manipulation in the modern business world must be avoided. God's will and the messages from Prophet Muhammad S.A.W should be followed by managers if they want to succeed in the world and the afterlife. When applied in a ' $k a f f a h$ ' manner, Islamic HRM Practices will be able to make the organization develop rapidly in the long run. Most MSMEs in Pekalongan turned 
out to choose imitation strategy and have an alignment with conservative HRM practices, or more emphasize on efficiency aspect. This means that the company emphasizes: (1) informal and short-term planning, simplified positions in the organization (2) prioritizing internal resources with closed procedures; (3) evaluating short-term performance; (4) standard or even low salary packages; (5) spontaneity and short-term offered training.

As the owner or manager of MSMEs, they are fully aware of the level of batik competition in their region. They tend to do the learning process of supply chain through the slogan "learning by doing", which also means that it is better to do something than nothing. Sometimes, they do something they do not understand at first. Besides, the source of knowledge about supply chain is obtained from internal party between individual in the organization, rather than the external party. They tend to do their job in their specialty and only pursue one certain job field while doing it continuously. As a result, they lack of innovation in looking for knowledge related to the supply chain problem in their organization. They also become less innovative because they are not looking for knowledge from external party. Even so, this condition does not occur for some MSMEs in Pekalongan because there are some MSMEs that are innovative and creative in carrying out the learning process of supply chain of their companies. They tend to be more proactive in searching for knowledge and implementing it starts from the search for raw material until product distribution.

These managers realize that all members of the organization have to study seriously and continue to follow the information and knowledge that keep developing. This is because the level of batik industry competition is very volatile. Uniquely, based on the interviews with owners/managers, it is stated that they are not reluctant to pass on their knowledge to their staff/colleagues about the production process up to selling skills. The entrepreneurs even provide opportunities to their staff if they want to resign and become entrepreneurs on their own. There is no jealousy and envy among others, sometimes they even collaborate with each other. Those who fail to become entrepreneurs will be accepted happily and openly if they want to return to be employees. This seems to be a social capital for them because they live in the environments that embed high religiosity. This is what makes the two aspects that are studied have a significant impact on social and religious performance. They also have a religion study groups which usually held every week and every month. This activity is used 
as a means of hospitality and maintaining harmony between one person and another. One of the interviewee stated that, "Work can be imitated, but fortune comes from Allah SWT." They do not care if people from other region or even their own region imitate their business because they know that everyone has their own fortune and it has already been arranged. By that, they are not worried about the additional competitors in their area. If they have been succeeded, their social soul is also very high because they will share some of their benefits for the poor (in Islam it is called Zakat, Infaq, and Shodaqoh). Every entrepreneur has their own spiritual teacher and they tend to follow the advice from them

Unfortunately, related to environmental problems, they are still not aware of the importance of a healthy and clean life with the surrounding environment, both the business environment and household environment. In general, they still dispose batik waste near their environment or river, so that it is easily polluted. However, the local government continues to provide awareness through training and socialization about the importance of healthy and clean life for MSMEs and the community. In certain groups, in the batik production, they already have their own creation of wastewater treatment plants because they are cheaper.

\section{Acknoledgement}

Our thanks go to the Directorate of Research and Community Service of the Ministry of Research and Technology of Indonesia (Kemenristek Dikti Indonesia) for funding this research in the scheme of Basic Research Grant of 2019/2020. We also thank DPPM UII as the institution that gave the approval to carry out this research. 


\section{References}

[1]. A.S, F., \& Arief, M. (2017). Pembelajaran Organisasi UMKM untuk Menciptakan Keunggulan Bersaing. Jurnal Ekonomi Modernisasi, 13(2), 105-118.

[2]. Ab. Rahman, N.M. N., Alias, M.A., Shahid, S., Hamid, M. A., \& Alam, S.S. (2013). Relationship between Islamic Human Resource Management (IHRM) practices and trust: An empirical study, Journal of Industrial Engineering and Management, 6(4): 1105-1123.

[3]. Ahmad, M.H. (2015). Impact of HR Practices on Organizational Performance: Moderating Role of Islamic Principles, Thesis, Alfalah Institute of Banking and Finance, Bahauddin Zakariya University, Multan, Pakistan.

[4]. Ali, A. J. (2010). Islamic challenges to HR in modern organizations. Personal Review, 39 (6), p. 692-711. https://doi.org/10.1108/00483481011075567

[5]. Alleyne, P., Doherty, L., \& Greenidge, D. (2006), Human resource management and performance in the Barbados Hotel Industry, International Journal of Hospitality Management, Vol. 25, Issue 4, p. 623-646. https://doi.org/10.1016/j.ijhm.2005.05.001

[6]. Azmi, I. A. (2015). Islamic human resource practices and organizational performance. Journal of Islamic Accounting and Business Research, Vol. 6 (1),p. 2-18. https://doi.org/10.1108/JIABR-02-2012-0010

[7]. Azmi, I.A.G. (2010). "Islamic human resource practices and organizational performance: a preliminary finding of Islamic organizations in Malaysia". Journal of Global Business andEconomics. Vol.1No.1,pp.27-42.

[8]. Bernadin, H.J., \& Russel, E.A. (1998), Human Resources Management; An Experiental Approach, Second Edition, International Editions, McGraw-Hill Companies, Inc.

[9]. Bolton, M.K. (1993). Imitation Versus Innovation: Lessons to Be Learned From the Japanese, Organizational Dynamics, 21(3): p. 30-45.

[10]. Bou, J. C., \& Beltran, I. (2005), TQM, High Commitment Human Resources Strategy and Firm Performance: An Empirical Study, Total Quality Management, Vol. 16, No. 1, January, p. 7186.

[11]. Delaney, J.T., \& Husehild, M.A. (1996). The Impact of Human Resources Management Practices on Perceptions of Organizational Performance, Academic of Management Journal, Vol. 39, No. 4, p. 949-969. https://doi.org/10.5465/256718

[12]. Farouk, S., Abu Elanain, H.M., , Obeidat, S.M., \& Al-Nahyan, M. (2016) "HRM practices and organizational performance in the UAE banking sector: The mediating role of organizational innovation", International Journal of Productivity and Performance Management, Vol. 65 Issue: 6, pp.773-791.

[13]. Farrukh, M. \& Waheed, A.(2015). Learning Organization and Competitive Advantage-An Integrated Approach. Journal of Asian Business Strategy, 5(4), pp.73-79. DOI: 10.18488/journal.1006/2015.5.4/1006.4.73.79

[14]. Gorelick, C.(2005). Organizational Learning vs The Learning Organization: a Conversation with a Practitioner. The Learning Organization, 12(4), pp.383-388. 
[15]. Hamidin, D., \& Surendro, K. (2010). Model Suplly Chain dalam Perspektif Teknologi, Proceeding, Seminar dan Call paper Aptikom, Politeknik Telkom, 9 Oktober 2010.

[16]. Hitt, M., Bierman, L., Shimizu, K., \& Kockhar, R. (2001). Direct and moderate effects of human capital on strategy and performance in professional service firms: A Resource based perspective, Academy of Management Review, Vol. 44 No. 1, pp. 13-28

[17]. Hurley, R.F,. \& Hult, G.T.M. (1998). Innovation, market orientation, and organizational lear ning : An Integration and empirical examination, The Journal of Marketing, Vol. 62, pp.4254.

[18]. Husehild, M. A (1995), The Impact of Human Resources Management Practices on Turnover, Productivity, and Corporate Financial Performance, Academic Management Journal, Vol 38, No. 31, p. 635-672.

[19]. Huselid, M. A., Jackson, S.E., \& Shuler, R.S (1997), Technical and Strategic Human Resource Managementt Effectiveness as Determinant of Firm Performance, Academic Management Journal, Vol 40, No. 1, p. 171-188.

[20]. Ikhwan. (2017). Penerapan Organisasi Pembelajar Dalam Meningkatkan Kinerja Rantai Pasok pada SPR Maju Bersama Bojonegoro, Tesis, Sekolah Paskasarjana, Institut Pertanian Bogor.

[21]. Imran, M.K., Ilyas, M., \& Aslam, U.(2016). Organizational Learning Through Transformational Leadership, The Learning Organization, Vol. 23 No. 4 p. 232-248.

[22]. Jimenez-Jimenez, D., \& Sanz-Valle, R. (2005). Innovation and human resource fit: an empirical study. International Journal of Manpower, 36(4), 364-398.

[23]. Jyoti, J., Chahal, H., \& Rani, A. (2017), Role of Organizational Learning and Innovation in between High-performance HR Practices and Business Performance: A Study of Telecommunication Sector, Vision: The Journal of Business Perspective, Volume: 21 issue: 3, page (s): 259-273.

[24]. Lei, D., Hitt, M., \& Bettis, R. (1996). Dynamic Core Competences through Meta Learning and Strategic Context, Journal of Management, Vol. 22 No. 4, pp. 549-569

[25]. Miles, R.E., \& Snow, C.C. (1978). Organization Strategy, Structure and Process. New York: McGraw-Hill.

[26]. Moideenkutty, U., Al Mmki, A., \& Murthy, S. R. (2011). HRM practices and organizational performance in Oman. Personal Review, 40, 2, 239-251.

[27]. Rana, M.H., \& and Malik, S. (2016) "Human resource management from an Islamic perspective: a contemporary literature review", International Journal of Islamic and Middle Eastern Finance and Management, Vol. 9 Issue: 1, pp.109-124.

[28]. Rana, M.H., \& Malik, M.S. (2017). Impact of human resource (HR) practices on organizational performance: Moderating role of Islamic principles", International Journal of Islamic and Middle Eastern Finance and Management, Vol. 10 Issue: 2, pp.186-207.

[29]. Rowley, J.(2006). The Library as A Learning Organization. Library Management, 18(2), pp. 88-91. 
[30]. Schuler, R. S., \& Jackson, S.E. (1987). Linking competitive strategy with Human Resources Management Practices, Academic of Management Executive, I (3), p. 207-219.

[31]. Stelmaszczyk, M. (2016). Relationship between individual and organizational learning: Mediating role of team learning. Journal of Economics and Management, 26 (4), p. 107-127.

[32]. Walton, R.E., \& Lawrence, P.R. (1985). Human Resource Management: Trendsand Challenges. Harvard Business School Press. Boston, MA 